\title{
EFEKTIFITAS PENANGGULANGAN GELANDANGAN DAN PENGEMIS DI KABUPATEN TULUNGAGUNG (Studi di Kantor Satuan Polisi Pamong Praja Kabupaten Tulungagung)
}

\author{
Devita Yulia Sari ${ }^{1)}$, *AA Bakar ${ }^{2)}$ \\ 1) Program Studi Administrasi Publik Universitas Kadiri, Indonesia \\ 2) Program Studi Administrasi Publik Universitas Kadiri, Indonesia \\ *Email Korespondensi : aabakar@unik-kediri.ac.id
}

\begin{abstract}
Abstrak
Perkotaan dipandang lebih menjanjikan untuk mencari pekerjaan sehingga bisa merubah nasib mereka. Namun hal ini tidak diimbangi dengan kemampuan sumberdaya manusia, sehingga yang terjadi justru sebaliknya. Kaum urban tersebut kesulitan memperoleh pekerjaan, kesulitan untuk memperoleh tempat berteduh. Akibatnya yang terjadi adalah mereka mengemis untuk bertahan hidup dan menggelandang (gepeng). Permasalahannya adalah bagaimana penanggulangan pengemis dan gelandangan di Kabupaten Tulungagung, dan faktor apa yang menjadi kendalan dalam pengendalian tersebut?. Adapun teknik penentuan informan dengan teknik purposive, sehingga dihasilkan informan kunci antara lain kepala Satuan Polisi Pamong Praja, kepala Seksi Operasional dan PAM pada Satuan Polisi Pamong Praja dan perwakilan dari gelandangan dan pengemis. Hasil penelitiannya adalah: (1) Satuan Polisi Pamong Praja (Satpol PP) melakukan razia. (2) Pengemis dan gelandangan yang terkena razia didata atau diinventarisir yaitu mengisi biodata. (3) dilakukan pembinaan. (4) kembalikan lagi ke kampung halamannya. Adapun secara eksternal tidak adanya Panti Sosial serta kurangnya kerjasama dengan dinas terkait lainya, dalam hal ini Dinas Sosial.Pengendalian pengemis dan gelandangan di kabupaten Tulungagung kurang efektif, sebab pengemis dan gelandangan setelah didata, dibina dan dipulangkan ke kampung halamannya kembali lagi mengemis dan menggelandang.
\end{abstract}

Kata Kunci: Pengemis; Gelandangan; Pengendalian

\begin{abstract}
Cities are seen as more promising to find work so that it can change their fortunes. However, this is not matched by the ability of human resources, so the opposite happens. These urbanites have difficulty getting a job, finding it difficult to find shelter. As a result what happens is they beg to survive and wander (flattened). The problem is how to deal with beggars and homeless people in Tulungagung Regency, and what factors are the constraints in controlling them? As for the technique of determining informants using a purposive technique, key informants were produced,
\end{abstract}


including the head of the Civil Service Police Unit, the head of the Operational Section and PAM in the Civil Service Police Unit and representatives of homeless people and beggars. The results of the research are: (1) The Civil Service Police Unit (Satpol PP) conducts raids. (2) Beggars and vagabonds who have been raided are recorded or inventoried, namely filling out biodata. (3) guidance is carried out. (4) return to his hometown. As for externally the absence of Social Institutions and the lack of cooperation with other related agencies, in this case the Social Service. Control of beggars and homeless people in Tulungagung district is ineffective, because beggars and vagrants after being recorded, fostered and sent back to their hometowns return to begging and homeless.

Keywords: Beggars; Bums; Control

\section{PENDAHULUAN}

Setiap pelaksanaan pembangunan sudah tentu memiliki dampak baik yang bersifat positif maupun negatif. Oleh karena itu harus terus dikembangkan dampak positif dari pembangunan tersebut dan mengurangi atau meminimalisir dampak negatif dari pembangunan. Salah satu bentuk dampak negatif dari pembangunan itu sendiri adalah adanya pengemis dan gelandangan yang ada di kota Tulungagung. Sebab setiap pelaksanaan pembangunan memerlukan pola adaptasi dari masyarakat terhadap proses dan hasil pembangunan itu sendiri, jika masyarakat tidak mampu beradaptasi dengan laju pergerakan pembangunan, maka yang terjadi adalah adanya pengemis dan gelandangan. Agar masyarakat dpat mengimbangi percepatan pergerakan laju pembangunan perlu adanya peningkatan kemampuan sumberdaya manusia.

Ketidak selarasnya antara pembangunan di perkotaan dengan pembangunan yang dilaksanakan di pedesaan menyebabkan perbedaan yang semakin jauh, antara wajah desa dan profil perkotaan. Perbedaan tersebut telah mendorong terjadinya arus urbanisasi dari desa kekota. Perkotaan dipandang lebih menjanjikan untuk mencari pekerjaan sehingga bisa merubah nasib mereka. Namun hal ini tidak diimbangi dengan kemampuan sumberdaya manusia, sehingga yang terjadi justru sebaliknya. Mereka kaum urban tersebut kesulitan memperoleh pekerjaan, kesulitan untuk memperoleh tempat berteduh. Akibatnya yang terjadi adalah mereka mengemis untuk bertahan hidup dan menggelandang, yang kemudian dikenal dengan Gepeng (pengemis dan gelandangan). Hal demikian terjadi karena mereka merasa malu kembali ke desa, dan mungkin harta kekayaan yang ada di desa sudah habis dijual, guna untuk merantau ke kota. 
Masalah umum gelandangan dan pengemis pada hakikatnya erat terkait dengan masalah ketertiban dan keamanan yang menggangu ketertiban dan keamanan di daerah perkotaan. Keberadaan pengemis dan gelandangan menjadi potensi terjadinya gangguan ketertiban dan keamanan warga kota (warga kota merasa terancam, sehingga kota menjadi tidak aman). Hal tersebut akan bermuara pada gangguan stabilitas keamanan, masyarakat menjadi gelisah, tidak tentram dan tidak nyaman.Kondisi demikian jika dibiarkan berdampak pada gangguan kelancaran pembangunan, yang pada gilirannya dapat menghambat ketercapaian cita-cita nasional. Oleh karena itu diperlukan solusi yaitu guna penanggulangan gepeng tersebut.

Walaupun sudah diupayakan agar tidak terjadi gepeng, namun tampaknya gepeng tetap menjadi masalah dari tahun ketahun, walaupun telah diusahakan upaya penanggulanganya. Setiap saat pasti ada sejumlah gepeng yang terkena razia dan dikembalikan ke daerah asalnya setelah diberikan upaya pembinaan.Penanggulangan gepeng akan mampu mewujudkan stabilitas nasional, khususnya stabilitas pertahanan dan keamanan sehingga diperlukan suatu studi yang menggambarkan secara utuh. Gambaran gejala gepeng ini dipakai untuk merumuskan kebijakan, strategi dan langkah-langkah penanggulangan gepeng.

Fenomena sosial adanya gelandangan dan pengemis di kota-kota sudah menjadi pemandagan sehari-hari, tidak terkecuali Kabupaten Tulungagung.Keberadaan Gepeng di Kabupaten Tulungagung semakin lama mengalami peningkatan drastis. Sebut saja di kawasan perempatan jalan, perkampungan, pasar, terminal, stasiun dan tempat ibadah seringkali dijadikan sasaran mangkal oleh para gepeng. Bukan hanya itu, di waktu perayaan hari-hari besar keagamaan jumlah gepeng di jalanan Kabupaten Tulungagung semakin bertambah dua kali lipat dari biasanya. Hal ini mengakibatkan dampak negatif bagi kota yaitu dapat mengganggu kenyamanan dan ketentraman warga, selain itu juga dapat mengotori lingkungan.

Sejauh ini contoh kebijakan yang telah direalisasikan oleh pemerintah Kabupaten Tulungagung melalui Satuan Polisi Pamong Praja (Satpol PP) adalah melakukan razia gelandangan dan pengemis untuk selanjutnya dibawa ke Kantor Satuan Polisi Pamong Praja untuk di data, dibina dan diberikan motivasi sehingga mereka tidak kembali lagi ke jalanan. Sedangkan respon para gelandangan dan pengemis terhadap kebijakan seperti ini, 
adalah tidak memperdulikan kebijakan tersebut dikarenakan tidak adanya ketegasan dan tindak lanjut dalam kebijakan tersebut, juga karena tidak ada sanksi hukum yang jelas, menjadikan para pengemis merasa sepele dengan peringatan Satpol PP. Hal ini membuat mayoritas pengemis yang terjaring razia kembali lagi ke profesinya sebagai pengemis. Permasalahan inilah yang melatarbelakangi penulis untuk mengkaji lebih dalam mengenai sistem penanganan gelandangan dan pengemis oleh pemerintah Kabupaten Tulungagung, khususnya oleh Satuan Polisi Pamong Praja Kabupaten Tulungagung yang bertanggung jawab atas permasalahan gepeng.

Fenomena-fenomena yang telah terlihat tentunya sudah menjadi tugas dari seluruh komponen masyarakat dan aparatur negara lainnya untuk berpikir lebih dalam mengenai penanganan permasalahan gepeng dan hal ini tidak terlepas dari peranan Satpol PP di Kabupaten Tulungagung. Permasalahannya adalah apakah hal ini sudah ditangani secara serius secara berkala dan berkelanjutan, Bagaimana pemerintah menanggulangi permasalahan tersebut, apakah cara-cara atau kebijakan yang dikeluarkan untuk menangani persoalan tersebut sudah efektif ? dan bagaimana pula dengan faktor kendala baik internal maupun eksternal ?

\section{TINJAUAN PUSTAKA}

Menurut (Fuadah, 2018), efektivitas adalah pemanfaatan sumber daya, sarana dan prasarana dalam jumlah tertentu yang secara sadar ditetapkan sebelumnya untuk menghasilkan sejumlah pekerjaan tepat pada waktunya. Berdasarkan konsep Abdurrahmad tersebut dapat diambil sarinya bahwa dalam efektifitas terkandung terlaksananya semua tugas, tercapainya tujuan, ketepatan waktu, dan partisipasi aktif dari yang sedang menjalankan serta adanya keterkaitan atau kesesuaian antara tujuan dan hasil. Oleh karena itu banyak faktor yang harus dipenuhi agar segala sesuatu dapat berjalan efektif atau efektifitasnya tinggi.

(Safuridar, 2017) menjelaskan bahwa efektifitas suatu kegiatan dapat dicapai apabila berbagai faktor tersebut dapat dipenuhi, faktor tersebut antara lain tugas atau fungsinya berjalan dengan baiuk, adanya rencana atau program kegiatan, fungsi dari aturan atau ketentuan yang telah ditetapkan, tujuan yang telah ditetapkan. Oleh karena itu 
pencapaian suatu tujuan organisasi atau perusahaan biasanya dapat diukur dengan tingkat efektivitas dari suatu kegiatan untuk mencapai tujuan tersebut. Semakin besar kontribusi keluaran yang dihasilkan terhadap nilai pencapaian sasaran, maka dapat dikatakan efektif organisasi atau perusahaan tersebut.

Suatu kegiatan dapat dikatakan efektif apabila tujuan sebenarnya berbanding tujuan yang direncanakan mempunyai hasil sama (Yanuarita \& Sakra, 2019) Atau dengan kata lain, efektivitas adalah keadaan yang muncul dan memungkinkan adanya suatu keberhasilan dari sebuah tindakan atau perbuatan yang dikehendaki dalam mencapai tujuan organisasi. Apabila output yang direncanakan lebih besar daripada output yang sebenarnya harus dicapai, maka dapat dikatakan keluaran atau kegiatan ini kurang efektif. Sebaliknya apabila output yang direncanakan lebih kecil daripada output yang sebenarnya harus dicapai, maka dapat dikatakan keluaran kegiatan ini efektif.

Pendekatan efektifitas tersebut dilakukan guna untuk mengukur sejauh mana suatu kegiatan tersebut efektif. Dalam hal ini (Salim et al., 2018) menjelaskan bahwa terdapat beberapa pendekatan dalam efektifitas, antara lain pendekatan sasaran, yaitu pendekatan yang mencoba mengukur sejauh mana sasaran tersebut dapat dicapai. Pendekatan sumber yaitu pendekatan efektifitas yang mengukur sejauh mana keberhasilan lembaga dalam melakukan kegiatan guna untuk memperoleh berbagai sumber yang diinginkan. Pendekatan proses yaitu suatu pendekatan efektifitas yang mendasarkan pada proses atau hasil suatu kegiatan sangat dipengaruhi oleh prosesnya.

Mengenai bagaimana pengukuran suatu kegiatan tersebut dikelompokkan efektif atau tidak. Menurut Strees dalam (Tangkilisan, 2005) menuturkan bahwa ada 5 kriteria dalam pengukuran efektifitas, antara lain produktivitas, kemampuan adaptasi kerja, kepuasan kerja, kemampuan berlaba, dan pencarian sumber daya.

Kepuasan menjadi ukuran organisasi memenuhi kebutuhan karyawan dan anggotanya. Organisasi sebagai suatu sistem sosial menuntut agar diperhatikan berbagai pertimbangan yang bermanfaat bagi anggota perusahaan sendiri maupun bagi konsumen. Kepuasan dan moral adalah ukuran yang serius untuk menunjukan tingkat organisasi memenuhi kebutuhan anggota. Ukuran kepuasan mencakup didalamnya sikap karyawan, pergantian karyawan, absensi dan keluhan keluhan. 
Keadaptasian: adalah suatu ukuran ketanggapan organisasi terhadap tuntutan perubahan. Keadaptasian dalam hal ini menunjukan kemampuan manajemen mengidera perlunya perubahan dalam lingkungan termasuk perubahan dalam tubuh organisasi sendiri.Pengembangan: Kriteria ini mengukur kemampuan organisasi untuk meningkatkan kapasitas menghadapi tuntutan lingkungan usahanya. Suatu organisasi harus melakukan berbagai upaya untuk memperbesar kesempatan kelangsungan hidup jangka panjangnya. Usaha dalam hal ini yang dilakukan adalah program pelatuhan manajerial melalui pendekatan psikologis dan sosiologis.

Era otonomi daerah pada dasarnya memberikan porsi kue ekonomi yang lebih besar kepada daerah untuk mendorong kemandirian daerah. Artinya daerah kini memiliki peran lebih untuk meningkatkan ekonomi lokal di daerahnya sendiri tanpa harus terus bergantung kepada pemerintah pusat (Marwanto \& Suwarno, 2019). Merujuk pada salah satu orientasi tugas Satuan Polisi Pamong Praja khususnya di Kabupaten Tulungagung adalah melakukan penanggulangan terhadap berbagai tindak yang bertentangan dengan ketentuan masyarakat. Maka terhadap siapa saja yang melakukan perbuatan yang dapat meresakhan, mengganggu ketertiban umum, membuat onar, membuat masyarakat menjadi resah. Maka hal tersebut menjadi wilayah Satuan Polis Pmong Praja yang bertindak mennggulangi hal tersebut agar kembali normal seperti sedia kala. Adapun penanggulangan menurut Kamus Besar Bahasa Indonesia adalah, proses, cara, perbuatan menanggulangi. Jadi Pengertian penaggulangan disini adalah proses atau cara untuk menanggulangi permasalahan gelandangan dan pengemis oleh Satpol PP Kabupaten Tulungagung.

Istilah "Gepeng” merupakan singkatan dari gelandangan dan pengemis. Menurut Departemen Sosial R.I (2005), gelandangan adalah orang-orang yang hidup dalam keadaan tidak sesuai dengan norma-norma kehidupan yang layak dalam masyarakat setempat serta tidak mempunyai tempat tinggal dan pekerjaan yang tetap di wilayah tertentu dan hidup mengembara di tempat umum.

Menurut Kamus Besar Bahasa Indonesia, Gelandangan mempunyai arti sebagai berikut berjalan kesana sini tidak tentu tujuanya, berkeliaran, bertualangan, Orang yang tidak tentu kediamanya dan pekerjaanya(Poerwadarminta, $1990: 261)$. 
Pasal 1 Peraturan Pemerintah Republik Indonesia No. 31 Tahun 1980 tentang Penanggulangan Gelandangan dan Pengemis, yang berbunyi :“ Gelandangan adalah orang-orang yang hidup dalam keadaan tidak sesuai dengan norma dan kehidupan yang layak dalam masyarakat setempat, serta tidak mempunyai tempat tinggal dan pekerjaan yang tetap diwilayah tertentu dan hidup mengembara ditempat umum. Sedangkan pengemis adalah orang-orang yang mendapatkan penghasilan dengan meminta-minta dimuka umum dengan pelbagai cara dan alasan untuk mengharapkan belas kasihan dari orang lain"

Berdasarkan konsep gepeng dari pasal 1 peraturan pemerintah Indonesia no. 31 tahun 1980 karakteristik dari gepeng antara lain : tidak memiliki tempat tinggal, hidup miskin, hidupnya serba tidak pasti, pakaian yang apa adanya/lusuh, Adapun faktor penyebab gepeng antara lain masalah kemiskinan, masalah pendidikan, masalah keterampilan kerja, masalah sosial budaya. Dampak dari gepeng antara lain : masalah lingkungan, masalah kependudukan, masalah kemanan dan ketertiban, masalah kriminalitas. demi untuk mendapatkan uluran tangan masyarakat di sekelilingnya. Mulai dari meminta - minta mengulurkan tangan bahkan mereka berani mengatas namakan sebuah mushala, pesantren dan sebagainya untuk kepentingan mereka. Padahal jika ditanya, mereka sendiri tidak mengetahui pesantren dan mushalla yang dimaksud dimana. Bahkan lebih parahnya lagi mereka minta dengan paksaan.

Maraknya jumlah gelandangan dan anak-anak jalanan di tengah- tengah kota tentu mengindikasikan meningkatnya tingkat kemiskinan kota yang pada akhirnya mengemis dan jadi gelandangan bukan nasib tapi pilihan mereka. Namun hakekatnya persoalan mereka bukanlah kemiskinan belaka, melainkan juga eksploitasi, manipulasi, ketidakkonsistenan terhadap cara-cara pertolongan baik oleh mereka sendiri maupun pihak lain yang menaruh perhatian terhadap Anak Jalanan dan Gepeng.

Ada beberapa faktor sosial budaya yang mempengaruhi seseorang menjadi gelandangan dan pengemis, yaitu : rendahnya harga diri pada sekelompok orang, mengakibatkan tidak dimilikinya rasa malu untuk meminta-minta, sikap pasrah pada nasib, kebebasan dan kesenangan hidup menggelandang. Ada kenikmatan tersendiri bagi sebagian besar gelandangan dan pengemis yang hidup menggelandang, karena mereka 
merasa tidak terikat oleh aturan atau norma yang kadang-kadang membebani mereka, sehingga mengemis menjadi salah satu mata pencaharian (Dirjen Pelayanan dan Rehabilitasi Sosial Depsos RI, 2005 : 7-8).

Adapun ciri-ciri gelandangan dan pengemis : anak sampai usia dewasa, tinggal disembarang tempat dan hidup mengembara atau menggelandang ditempattempat umum, biasanya dikota-kota besar, tidak mempunyai tanda pengenal atau identitas diri, berperilaku kehidupan bebas atau liar, tidak mempunyai pekerjaan tetap, meminta-minta atau mengambil sisa makanan atau barang bekas. (Dokumen Bagian Sosial Pemda, 2003).

Satuan Polisi Pamong Praja disingkat, Satpol PP, adalah perangkat pemerintah daerah dalam pemeliharaan ketentraman dan ketertiban umum serta menegakan peraturan daerah. Organisasi dan tata kerja Satuan Polisi Pamong praja ditetapkan dengan peraturan daerah. Satpol PP dapat berkedudukan di daerah provinsi dan Kabupaten / Kota.Di Kabupaten / Kota, Satuan Polisi pamong Praja dipimpin oleh Kepala yang berada dibawah dan bertanggung jawab kepada Bupati melalui Sekertaris Daerah.

Dalam Peraturan Daerah kabupaten Tulungagung no 7 Tahun 2012. Bab I Pasal 1: membicarakan masalah ketertiban, ketertiban umum tersebut terbentuk karena tidak adanya terjadi berbagai pelanggaran di tempat umum. Berdasarkan kondisi demikian harapannya tercipta kehidupan yang aman, tentram, dinamis namun teratur. Mingingat wilayah kerja satpol PP adalah tempat umum, yaitu suatu wilayah yang dikelola oleh swasta/pemerintah yang diperuntukan untuk kepentingan umum, yang meliputi berbagai gedung, stadion, pasar, terminal dan lain sebagainya.

Isi dari bab I pasal 1 Perda Tulungagung no 7 tahun 2012 tidak hanya yang tersebut di atas, akan tetapi juga meliputi pedagang kaki lima, Tuna Sosial adalah penyandang masalah kesejahteraan sosial termasuk diantaranya gelandangan, pengemis, pengamen dan tuna susila.Tuna Susila adalah orang yang mengadakan hubungan seksual tanpa didasari dengan perkawinan yang sah dengan imbalan/upah sebagai balas jasa.Penjaja Seks Komersial adalah seseorang yang mempunyai mata pencaharian dengan cara memberikan pelayanan seksual di luar perkawinan kepada siapa saja dari jenis kelamin berbeda yang tujuannya untuk mendapatkan imbalan uang.Gelandangan adalah orangorang yang hidup dalam keadaan tidak sesuai dengan kehidupan normal yang layak dalam 
masyarakat setempat, serta tidak mempunyai tempat tinggal dan pekerjaan yang tetap diwilayah tertentu dan hidup mengembara ditempat umum. Pengemis adalah perbuatan meminta-minta baik lisan maupun tulisan yang dilakukan ditempat umum, yaitu di jalanjalan dan ditempattempat yang dapat dilihat oleh masyarakat, serta pengamen.

Ketentraman, ketertiban umum, dan upaya harmonisasi kehidupan bermasyarakat menjadi tanggung jawab bupati. Adapun masalah pengendalian, penyelenggaraan ketertiban umum dan ketentraman dilakukan oleh Satuan kerja terkait di dinas lainnya. Sementara itu pembinaannya dilakukan oleh Satuan Polisi Pamong Praja bersama dengan penyidik Aparatur Sipil Negara (pasal 41 Perda Tulungagung). Masalah ketentrmn, kedamaian dan keharmonisan dalam kehidupan bermasyarakat menjadi tanggungjawab kita bersama. Oleh karena itu setiap warga masyarakat dituntut untuk berpartisipasi dalam upaya menciptakan kedamaian, ketentraman dan keharmonisan kehidupan bermasyarakat tersebut. Jika kita sebagai anggota masyarakat mengetahui adanya pelanggaran atas ketertiban dan ketentraman dan diam saja, maka artinya kita tidak berpartisipasi untuk itu dikenakan sanksi oleh pemerintah, hal ini sesuai dengan pasal 42 ayat 2.Setiap petugas yang dilapori terjadinya tindak pelanggaran ketertiban atau ketentraman wajib menindaklanjuti, jika tidak maka ppetugas tersebut bisa dikenakan sanksi disiplin, disamping juga bisa dikenai sanksi administrasi.

\section{METODE PENELITIAN}

Pendekatan yang digunakan untuk melakukan penelitian ini adalah penelitian kualitatif yaitu "penelitian yang berakar pada alamiah sebagai keutuhan, mengandalkan manusia sebagai obyek penelitian bersifat deskriptif lebih mementingkan proses daripada hasil, membatasi studi dengan fokus, memiliki seperangkat kreteria untuk memeriksa keabsahan data, rancangan penelitiannya disepakati oleh kedua belah pihak, peneliti maupun obyek penelitiannya (Flick, 2013). Dalam penelitian ini tidak menekankan pada hasil melainkan pada proses penelitian. Lebih lanjut pendekatan penelitian ini diarahkan pada situasi dan individu atau organisasi ke dalam variabel atau hipotesis tetapi perlu memandangnya sebagai bagian dari suatu keutuhan. 
Hal ini sesuai dengan sifat pendekatan deskriptif yang mengikuti pola pemikiran empirical inductive, yakni segala sesuatu dalam penelitian ini sangat ditentukan atau tergantung dari hasil pengumpulan data yang mencerminkan keadaan yang sesungguhnya dilapangan (Flick, 2013)

Adapun penelitian ini dilakukan di di Kantor Satuan Polisi Pamong Praja Kabupaten Tulungagung, yang terletak di jalan RA. Kartini Tulungagung. Obyek tersebut dipilih karena sebagai instansi yang terlibat langsung dalam pelaksanaan penertiban gelandangan dan pengemis. Sesuai dengan pendekatan kualitatif, maka data dikumpulkan merupakan deskriptif data, yaitu penjelasan dari suatu fenomena (Flick, 2013).

\section{HASIL DAN PEMBAHASAN}

Menurut data yang ada di kantor Satpol PP, bahwa gepeng tersebar di beberapa titik mangkal di Kabupaten Tulungagung. Jumlah gepeng yang banyak adalah di perempatan-perempatan lampu merah, terutama yang lokasinya agak jauh dari kota atau daerah pinggiran yang luput dari patroli Satpol PP, dan di beberapa titik yang terindentifikasi adanya gepeng antara lain, pasar ngemplak, pasar wage, daerah pertokoan Belga dan di depan apotek, masjid dan sarana ibadah lainya serta toko-toko yang sekiranya ramai oleh para pengunjung.

Gepeng di Kabupaten Tulungagung setelah terkena razia, didata, diinventarisir, kemudian diberikan pembinaan kemudian dikembalikan ke daerah asalnya. Hal ini sebagaimana dituturkan oleh petugas Satpol PP "Mereka yang pernah terjaring razia gabungan oleh Satpol PP dan Dinas Sosial Kabupaten Tulungagung, kemudian dikembalikan ke daerah asal mereka masing-masing”. Gepeng di Tulungagung berasal dari daerah sekitar, misalnya kediri, Blitar maupun Trenggalek. Hal ini seperti yang diungkapkan gepeng yang penulis temui di Kantor Satpol PP saat mereka terjaring razia, ada yang berasal dari Ponorogo (Sumini), saya dari Trenggalek (Ngatiyem) dan saya dari Kediri (Tarno). Mereka lebih suka menggepeng di luar wilayahnya, agar tidak malu (Tarno Kediri), Hal itu didukung oleh pernyataan Ngatinem dan Ngatiyem, sebab kalau menggepeng di daerahnya sendiri malu kalau bertemu tetamgga. 
Ada beberapa alasan mengapa seseorang menjadi gepeng. Faktor utama yang menyebabkan seseorang menjadi pengemis adalah faktor ekonomi. Hal ini merupakan alasan yang klasik bahwa alasan tersebut merupakan faktor yang utama yang diungkapkan oleh para gepeng. Selain faktor kemiskinan ada faktor lain yang menyebabkan seseorang untuk menjadi gepeng, yaitu faktor yang datang dari lingkungan keluarga yang tidak harmonis (broken home), orang tua bercerai dan tidak memperdulikan keinginannya. Disamping karena sulitnya mencari pekerjaan yang disesbabkan karena rendahnya pendidikan yang dimiliki, sehingga mereka tidak mampun bersaing dengan pencari kerja lain.

Gepeng yang terjaring operasi atau razia yang dilakukan oleh polisi pamong praja yang bekerja sama dengan dinas terkait, kemudian di data, artinya dicatat sesuai dengan jenis kelamin, umur, status, asal-usul, pendidikan, agama, dan alasan menggelandang. Setelah dilakukan pendataan yang bersangkutan dilepas kembali, bisa dikembalikan ke daerah asal bisa juga dilanjutkan dengan pembinaan. Berdasarkan pendataan tersebut, pada umumnya gepeng yang terjaring razia di kabupaten Tulungagung pada umumnya berasal dari luar, bisa dari kabupaten Blitar, Kabupaten/kkota Kediri maupun Kabupaten Trenggalek, ada juga yang berasal dari Ponorogo.

Dalam melakukan razia terhadap gelandangan dan pengemis, apabila ditemukan adanya gelandangan dan pengemis di perempatan-perempatan ataupun tempat keramaian lainya dimana sering dijadikan tempat untuk melakukan pengemisan maka akan dibawa ke kantor Satpol PP untuk kemudian didata dan diserahkan kepada dinas terkait dalam hal ini adalah Dinas Sosial Kabupaten Tulungagung.

Berdasarkan jenis kelamin, sebagian besar yang menggelandang adalah kaum perempuan dan anak-anak. Adapun alasan menggelandang atau mengemis di luar daerahnya adalah, a. Mencari pekerjaan sulit, b. Adanya keinginan untuk bekerja dengan leluasa (sulit menyesuaikan diri dengan berbagai lingkungan kerja), c. Menggelandang dan mengemis di daerah sendiri malu jika sampai bertemu dengan orang yang dikenal, $d$. Alasan menggelandangan dan mengemis karena faktor kemiskinan.

Dalam pelaksanaan razia gabungan gelandangan dan pengemis oleh petugas Satpol PP dan Dinas Sosial, apabila mendapatkan hasil temuan gelandangan dan pengemis 
di jalan maka proses selanjutnya adalah dibawa ke Kantor Satpol PP untuk didata oleh petugas. Mereka yang terjaring razia akan didata dimana daerah asal mereka dan mengisi surat pernyataan untuk tidak melakukan kegiatan penggelandangan dan pengemisan lagi. Setelah selesai didata oleh petugas, maka untuk selanjutnya mereka akan diserahkan kepada Dinas Sosial Kabupaten Tulungagung untuk diberi pembinanaan. Bentuk pembinaan tersebut antara lain, diberi berbagai ketrampilan kerja, pembinaan moral, hidup bermasyarakat, diberi motivasi untuk selalu bekerja keras dalam kehidupan bermasyarakat.

Dalam upaya untuk menanggulangi gelandangan dan pengemis tidak selalu berjalan mulus. Seringkali para gelandangan dan pengemis yang dulu sudah pernah terjaring razia kembali lagi ke jalan untuk menggelandang dan mengemis. Dengan berbagai macam alasan mereka akan kembali lagi ke jalanan.Penyerahan para gelandangan dan pengemis ke pengadilan merupakan upaya yang diambil apabila mereka kembali terjaring razia oleh petugas dikemudian hari. Seperti yang dikemukan Yulius Rahma Isworo, SSTP, Kasi Pengendalian Operasional:“Penyerahan ke pengadilan untuk disidang tipiring merupakan langkah yang kami ambil apabila para gelandangan dan pengemis yang telah terjaring pada razia sebelumnya kembali lagi ke jalanan untuk melakukan aktifitas penggelandangan dan pengemisan. Hal ini sekaligus upaya untuk memberikan efek jera kepada mereka agar tidak mengulangi perbuatannya lagi dikemudian hari.

Penanggulangan gelandangan dan pengemis merupakan kegiatan rutin yang dilaksanakan oleh Satuan Polisi pamong Praja Kabupaten Tulungagung. Razia terhadap gelandangan dan pengemis dilakukan secara berkala yaitu setiap hari Kamis dan jumat setiap minggunya. Selain itu pada hari-hari biasa, pada saat patroli pagi, siang, dan malam juga tetap akan ditindak lanjuti apabila ditemukan gelandangan dan pengemis yang ada dijalan.

Proses pembinaan terhadap gelandangan dan pengemis yang dilakukan oleh petugas Satpol PP dan Dinas Sosial juga dirasa masih kurang efektif, karena petugas hanya mendata gelandangan dan pengemis yang ada, memberikan pengarahan moral dan saran agar tidak mengulangi perbuatanya lagi serta membuat surat pernyataan kepada para 
gelandangan dan pengemis tanpa adanya tindak lanjut pemberian keterampilan. Hal ini dikarenakan tidak adanya panti penampungan Dinas Sosial untuk pemberian modal keterampilan.

Kendala tersebut disebabkan secara internal, struktur organisasi yang membebankan semua urusan penanggulangan gelandangan dan pengemis kepada satu seksi, yaitu seksi pengendalian opersional kurangnya sarana dan prasarana kegiatan operasional lapangan serta perlunya intensitas pelatihan agar kinerja SDM lebih maksimal lagi. Adapun secara eksternal tidak adanya Panti Sosial di Tulungagung serta kurangnya kerjasama dengan dinas terkait lainya, dalam hal ini Dinas Sosial yang menangani urusan rehabilitasi terhadap gelandangan dan pengemis.

\section{KESIMPULAN}

Upaya pengendalian Gepeng di Kabupaten Tulungagung melalui cara merazia mereka secara berkala dan terstruktur tersebut kurang efektif. Hal ini disebabkan oleh Gepeng setelah dilakukan pendataan, pembinaan, pemberian bekal yang kemudian dipulangkan tersebut, ternyata kembali lagi kejalanan, dengan alasan yang sama,, yaitu sulitnya mencari pekerjaan, kemiskinan, kebebasan hidup. Oleh karena itu walaupun dilakukan pengendalian, dalam rangka menciptakan kota yang bersih, indah, dan aman, nyaman, tentram serta tertib, masih saja belum dapat terwujud dengan maksimal.

\section{REFERENSI}

Flick, U. (2013). The SAGE handbook of qualitative data analysis. Sage.

Fuadah, M. 2018. Ragam Program Dan Hambatan Dalam Penanganan Gelandangan Terhadap Keefektifitasan Program. The Journal of Society and Media, 2(2), 121129.

Marwanto, I. H., \& Suwarno, S. 2019. Reformasi Birokrasi Daerah: Variasi Inovasi Birokrasi Perizinan Pasca Otonomi Daerah. Mediasosian, Vol. 2(2).

Peraturan Pemerintah Republik Indonesia No. 31 Tahun 1980 tentang Penanggulangan Gelandangan dan Pengemis

Poerwadarminta, WJS. 1990. Kamus Besar Bhasa Indonesia. Balai Pustaka. Jakarta. 
Safuridar, S. 2017. Efektivitas Pinjaman Dana Bergulir PNPM Mandiri Perdesaan Terhadap Masyarakat Kurang Mampu (Studi Kasus Desa Paya Bedi Kecamatan Rantau Kabupaten Aceh Tamiang). Jurnal Samudra Ekonomika, 1(2), 151-164.

Salim, Wilmar, Drenth, M., Humaira, A. N. S., Rifai, A., Handayani, R., \& Histiraludin, S. 2018. Access to Urban Services for Inclusive Development in Asia Country Monograph: Indonesia. Swedish International Centre for Local Democracy.

Tangkilisan, H. N. S. 2005. Manajemen publik. Grasindo.

Yanuarita, H. A., \& Sakra, T. 2019. Efektivitas Implementasi Program Gentasibu Di Kelurahan Begadung, Kecamatan Nganjuk, Kabupaten Nganjuk. Mediasosian, Vol. $3(2)$. 